\title{
CURIOUS LEGAL CONDITIONALS
}

\author{
LESZEK BEREZOWSKI \\ berezowscy@interia.pl \\ Wrocław University, Poland
}

\begin{abstract}
The paper examines the use of the modal verb SHALL in the if clauses of conditionals found in legal English. The study traces the history of such usages and compares them to two uses of WILL attested in the same grammatical environment: a temporal use and a nonepistemic modal use. The comparison provides the foundation for examining the use of SHALL in Biblical translations, where this verb has outlived its demise in general English, and both of these sources inform the analysis of SHALL in legal conditionals. Specifically, it is claimed that SHALL is not inherently deontic in legal English but is used as an explicit marker of the authority vested in the author or authors of spoken and written texts. This approach explains why authority conscious drafters can use SHALL in the if clauses of conditionals and in temporal clauses whenever they want to and why the proponents of the plain language movement advocate simply deleting SHALL from legal writing and not replacing it with more popular modals expressing deontic meanings, e.g. HAVE TO, MUST, etc. It is claimed that no such replacements are recommended because there is no deontic meaning to replace and the authority designated by SHALL can be inferred from the context.
\end{abstract}

Key words: legal English, modal verbs, SHALL, conditionals, temporal clauses

\section{Introduction}

The drafters of English legal documents are well known for their fond attachment to the modal verb SHALL. It has been noted in a number of studies that its use in legal texts is substantially more frequent than elsewhere in English (e.g. Williams 2007, WitczakPlisiecka 2009, Goźdź-Roszkowski forthcoming) and resilient enough to withstand so far the zealous calls to weed it out repeatedly made by the supporters of simplifying legal writing (e.g. Kimble 2000).

Given the contrast between the survival of SHALL in drafting contracts and legislation (Goźdź-Roszkowski forthcoming) and its almost complete disappearance from other kinds of written and spoken texts during the previous century (Leech et al (2009), it is no wonder that it has attracted quite much research. Based on extensive corpora scholars have studied the development of SHALL as a modal verb and future marker, e.g.: van Ostade (1985), Arnovick (1990), Gotti et al (2002) or Wischer (2006), its current standing in English, e.g.: Gotti (2003), Bergs (2008) or Leech et al (2009), the rise of SHALL in legal English, e.g.: Rissanen (2000) and its present use in legal drafting, e.g.: Klinge (1995) or Trosborg (1995), Conte and Di Lucia (2009) or WitczakPlisiecka (2009). 
However, all these studies have mostly stayed away from examining in any detail the use of SHALL in if clauses and an assortment of temporal clauses occasionally found in legal documents. Both atypical patterns are illustrated below by two recent examples: an excerpt from the terms and conditions of ordering medical equipment posted online in 2010 by Genetix Ltd., an English company headquartered in New Milton, Hampshire (1) and a clause found in an order issued by North Dakota Securities Department in 2008 (2):

(1) 2.6 If the Company shall cease to manufacture any Goods ordered by the Customer it shall give notice of the fact in writing to the Customer (but shall not be liable for any loss or damage occasioned thereby to the Customer) whereupon the Customer will have the option to be exercised within twentyone days of the date of such notice, either to take equivalent goods (if available from the Company) or to cancel its order without further liability upon the Company or the Customer.

(2) Pursuant to N.D.C.C. § 10-04-16, when it shall appear to the Commissioner that any person has engaged in, or is engaging in, or is about to engage in an act or practice which is declared illegal in this chapter, the commissioner may issue an order and collect civil penalties against any person found in an administrative action to have violated any provision of the chapter in an amount not to exceed $\$ 10,000$ for each violation.

The usages underlined above are relatively infrequent even in legal drafting and could be easily dismissed as antiquities to be swept away by the plain language movement but the insights into the role of SHALL in legal English offered by the curious grammar of such cases certainly make them worth exploring. This paper will do so by surveying scant previous scholarship on such uses of SHALL in section 2, tracing their origin in section 3 , examining their relationship to comparable uses of WILL in section 4 , offering an explanation in section 5 and pursuing its wider ramifications in section 6 .

\section{Previous scholarship}

Recent corpus studies of SHALL in legal English dutifully note only the existence of the pattern illustrated in (1) but the authors do not venture too far beyond stating that fact. For example Trosborg (1995) quotes an example with SHALL in the if clause repeated here as (3) below:

(3) The licence to reside in the premises [...] shall terminate automatically without any notice if the officer shall cease to reside in the premises or upon termination of this agreement.

and comments on it as follows:

Only the structure with shall in italics functions as a directive; the second shall (in the subordinate clause) is used as a condition on the illocution signalled in the main clause. (Trosborg 1995: 40) 
In other words she merely notes the fairly obvious point that the use of SHALL in if clauses does not serve to impose obligation on the addressee and goes on to examine other facets of legal English. Doing so does not explain much but passing over the problem in silence turns out to be benevolently neutral when compared with the opinions other scholars.

Discussing an essentially similar example Klinge (1995) is more radical both in admitting defeat in dealing with the problem and dismissing its importance:

Although it may not be an entirely satisfactory solution, the explanation is most likely that such data are the results of draftsmen's penchant for shall rather than semantics or systematic usage. In this context shall makes little sense both in this framework and in traditional frameworks. (Klinge 1995: 670)

In the final sentence of the comment Klinge admits that accounting for the use of SHALL in if clauses and a host of other subordinate clauses is well beyond the reach of extant approaches, whether they are built on the concept of deontic modality (e.g. Trosborg's model) or broader theories of discourse operators (e.g. Klinge's model). However, in the preceding sentence he tries to load the blame for the shortcomings of his model on the data he set out to explain by questioning their reliability and consistence.

The same dismissive attitude is voiced in Williams (2007), who likewise views the use of SHALL in if clauses as a harmless relic of the past that need not be bothered with or accounted for:

In such cases shall would seem to have no modal function whatsoever; it is purely ornamental, $[. .$.$] a legacy from the past which many contemporary drafters still$ adopt on the basis of a centuries-old tradition rather than for reasons of clarity. (Williams 2007: 120)

The temporal pattern illustrated in (2) is not even mentioned in studies devoted to the use of SHALL in legal English, which sadly underscores the point that previous scholarship has thus focused much more on evading the patterns exemplified above than on positing even the most tentative explanations. As will be shown in section 6 below this sad state of affairs is a consequence of the assumptions underlying the studies of SHALL reported on above.

\section{Historical background}

A brief look into the history of using SHALL in legal English if clauses is a more positive experience than reviewing the evasive comments surveyed above and exposes facts that eventually help uncover the rationale behind this curious grammatical pattern.

Both uses of SHALL illustrated above arose in early Middle English times as an alternative to if and temporal clauses formulated in the present tense and the subjunctive and they continued well into the eighteenth century. The last example noted in Visser (1963) comes from the writings of Coleridge, which means that the patterns finally disappeared from general English in the first half of the nineteenth century. However, in legal discourse the story is a bit different. 
The earliest example of legal usage dates from 1533, i.e. from the time when the use of SHALL in legal writing started mushrooming (Rissanan 2000: 114), and is found in the Appointment of Bishops Act, a piece of legislation that was instrumental in establishing the Church of England and remains in force until now:

(4) And yf any such nomynacion or presentment shall happen to be made for defaute of suche eleccion to the dignytie or office of any Archebishope then the Kynges Highnes his heires and successours, by hys letters patentes under hys greate seale, shall nomynate and present such person, as they wyll dispose to have the seid office and dignitie of Archebishopriche beyng voyde.

A century later the continuing use of the pattern is evidenced by An Ordinance for the better observation of the Lords - Day passed by the Long Parliament in 1644:

(5) And it is further Ordained, That if any of the said Officers shall neglect to do their Office in the Premises, within one week after the notice of this Ordinance, every of them, for such neglect shall forfeit Five Shillings of lawful Moneys; and so from week to week, weekly Five shillings more afterwards, till the said May-Pole shall be taken down, and removed.

The usage did not change much in the following century as shown by an excerpt from article 1 section 7 of the Constitution of the United States of America adopted in 1787:

(6) Every bill which shall have passed the House of Representatives and the Senate, shall, before it become a law, be presented to the President of the United States; [...] If any bill shall not be returned by the President within ten days (Sundays excepted) after it shall have been presented to him, the same shall be a law.

The pattern remained also in use more than a century later as evidenced by the following passage in the regulations governing the Balfour Studentship in Zoology drafted in 1904 and kept on the books of Cambridge University until now:

(7) If the Managers shall at any time learn that the Student is following any such business or profession, or has undertaken any such work, as would in their opinion interfere with the Student's inquiries, they shall at once call upon him or her to desist from the same, and if the Student shall refuse or neglect so to do they shall report the circumstances to the Board.

Finally, the pattern continues to be used nowadays as has already been shown in section 1 above and is witnessed again below by a provision culled from the general conditions of contracting services with the company operating Liverpool John Lennon Airport posted online in 2010:

(8) if the Company shall have a winding up order or administration order made against it or it shall enter into or become subject to a scheme, composition or voluntary arrangement with his creditors or there shall be commenced a winding-up dissolution administrative receivership or analogous proceedings of or in respect of the Company or any of the Company's assets then, without 
prejudice to any other remedy of the Group, it shall be lawful, without avoiding the Order, to take the work wholly or partially out of the hands of the Company and to employ another company to purchase the Goods or similar items or to carry out or complete the Services

While it is correct that the use of SHALL in legal English if clauses is quite an old pattern, as implied in the evasive comments in Klinge (1995) and Williams (2007), it is thus not true, as intimated by the same authors, that it is unsystematic and / or defunct. As shown above, it has continued in the same form for five centuries and has outlived the demise of the pattern in general English at least by a century and a half.

The fact that SHALL has not disappeared completely from if clauses and lingers on in legal usage is not in itself remarkable in any way as most language changes are incomplete and leave in their wake a residue of unaffected items or contexts that are then labeled exceptions and irregularities. What is striking, though, is that the change failed to affect the people who spend long years honing their language skills to perfection and enjoy high social status. Becoming a lawyer has always required completing several levels of formal education exposing students to grammar books and teachers whose combined pressure was usually quite effective as witnessed, for example, by the replacement of multiple negation with single negation in the language of educated speakers. Besides single negation lawyers have accepted the rise of perfect and progressive verb forms, the demise of the subjunctive in if clauses and several other grammar changes promoted by textbooks and the rejection of each of these developments could have become a hallmark of legal English. However, only the pressure to drop SHALL was stubbornly resisted on a large scale, which shows that the motivation to do so must have been much stronger than a mere penchant for grammatical relics. For instance lawyers may have continued to use SHALL in if and temporal clauses after its demise in general English because that verb designates a meaning that remains vital in law but has lost its significance elsewhere in society.

\section{Comparison with WILL}

Another modal verb that is found in if and temporal clauses is WILL. Given the fact that the case of WILL has been researched more fruitfully and is now better understood, it might be worthwhile to check if the accounts worked out for that modal verb could be extended to SHALL.

One meaning found to be profiled by WILL in if clauses is essentially temporal, e.g.:

(9) If it will amuse you, I'll tell you a joke.

The students of such atypical patterns, e.g. Comrie (1982), where this example comes from, or Declerck (1984) agree that the use of WILL illustrated in (9) is linked to the ordering of the events profiled by the two clauses of the conditional. The standard scenario is that the if clause designates and event which precedes the situation profiled by the result clause in the same fashion as causes precede their consequences. However, in cases like (9) this ordering is reversed in that the result clause profiles joke telling, i.e. 
the event that normally comes first, and the if clause designates amusement, i.e. the state that results from entertainment and occurs later.

Instead of stipulating a condition the if clause in (9) designates thus a future prediction, which requires the use of WILL. In other words WILL is dispensed with in the standard case when the if clause profiles a condition but it is indispensable in the nonstandard scenario described and illustrated above.

Unfortunately, it is not possible to extrapolate this account to cases where the modal verb used in the if clause is SHALL, e.g. the following excerpt of an act adopted by New Jersey legislature in 2009:

(10) If the director shall, in accordance with subsection a of this section, reduce the rate of tax imposed pursuant to PL 1966, c.30 to a rate of less than $3.5 \%$ during a tax reduction period, the Director shall immediately notify the State Treasurer of the rate and the terms and conditions for which tax shall be imposed during that tax reduction period and shall immediately submit a report to the Legislature, pursuant to section 2 of P.L. 1991, c. 164 (C.52:14-19.1) outlining the rate and the terms and conditions for which tax shall be imposed during that tax reduction period.

The reduction of the tax rate profiled in the if clause underlined above is a true condition profiling an event that has to precede each of the actions designated in the result clauses, i.e. notifying the state treasurer and filing a report with the state legislature. The order of the events profiled in (10) does not then follow the pattern that conditions the use of WILL in the if clause in (9), which means that the rationale for using SHALL in the if clause in (10) has to be looked for elsewhere.

The second use of WILL in if clauses is, however, more promising. As is well known WILL can designate in such clauses a variety of nonepistemic meanings illustrated below with examples quoted after Decleck and Reed (2001: 210-212):

(11) If your mother will cooperate, you might ask her these kinds of questions.

(12) Let's check in the brochure. If the boat will sleep eight people, none of us will have to go to a hotel.

(13) If Freedom Fighters will not give in - Quo Vadis, John Major ?

In (11) the use of WILL designates willingness on the part of the mother, i.e. a person who is not the addressee or, as lawyers prefer to say, a third party, in (12) WILL profiles an inherent capacity of the referent and in (13), along with the negation marker, it signifies refusal.

Since most or all uses of SHALL are described by grammarians as nonepistemic, the occurrence of that verb in if clauses could then in principle be analyzed along the same lines as above provided that it carries a suitable meaning. 


\section{Power and authority}

A good place to look for such a meaning seems to be an area of language use where SHALL has shown the same tenacity as in law and for decades defied changes prevailing elsewhere in English. A case in point is the language of Bible translations.

The strength of the resistance to give up on SHALL in that field of language use is aptly illustrated by the three following English versions of a well known gospel verse (St. Matthew 16: 26):

(14) For what is a man profited, if he shall gain the whole world, and lose his own soul? or what shall a man give in exchange for his soul? KJ 1611

(15) For what shall a man be profited, if he shall gain the whole world, and forfeit his life? or what shall a man give in exchange for his life? ASV 1901

(16) What good will it be for a man if he gains the whole world, yet forfeits his soul? Or what can a man give in exchange for his soul? NIV 1973

The translation in (14) comes from the King James Bible first printed in 1611, i.e. at a time when the use of SHALL in the if clause of a conditional was not in any way unusual (Visser 1963). However, the translation in (15) comes from the American Standard Version issued in 1901, well after SHALL had disappeared from if clauses in virtually all varieties of English except legal drafting. What is perhaps even more telling is the fact the American Standard Version is in fact a revision of the King James Bible and one of the goals of the editors was to update its grammar. They modernized verb morphology, brought up to date the use of relative pronouns and introduced a number of other changes, but decided to leave SHALL in if clauses intact.

As shown in (16), which comes from the New International Version released in 1973, this usage was finally discontinued, but it held out long enough to show that SHALL is the carrier of a meaning that is both precious to Bible scholars and hard to replace.

A good way to glimpse that meaning is to examine a biblical passage in which the use of SHALL continues until now, e.g. the wording of the Ten Commandments in the Book of Exodus 20:13-15. SHALL had already been used in the translation of that text well before the times of the King James Bible, e.g. the following excerpt from Wycliffe's Bible completed in the final two decades of the fourteenth century (Ellingworth 2007):

(17) ${ }^{12}$ Onoure thi fadir and thi moder, that thou be long lyuyng on the lond, which thi Lord God schal yyue to thee. ${ }^{13}$ Thou schalt not sle. ${ }^{14}$ Thou schalt do no letcherie. ${ }^{15}$ Thou schalt do no theft.

The usage obviously continued in the King James Bible:

(18) ${ }^{12}$ Honour thy father and thy mother: that thy days may be long upon the land which the LORD thy God giveth thee. ${ }^{13}$ Thou shalt not kill. ${ }^{14}$ Thou shalt not commit adultery. ${ }^{15}$ Thou shalt not steal. 
And was retained in the New International Version of 1973:

(19) ${ }^{12}$ "Honor your father and your mother so that you may live long in the land which the Lord your God is giving you. "13 "You shall not murder". "14 "You shall not commit adultery". "15 "You shall not steal".

The fact that the use of SHALL has survived so well in this passage is significant in that it is a most explicit example of law giving by a supreme authority equipped with the power to lay down biding rules and punish those who fail to follow them. God can certainly do both and given the correlation between His superior position with respect to creation and the use of SHALL in the translation of those scriptural passages where His dominion is directly exercised in formulating the commandments, SHALL may be claimed to be a grammatical marker of the supreme status of the speaker.

As shown in all three versions of verse 12 above, commandments might just as well be formulated in the imperative and without any recourse to SHALL, leaving the dominating position of the speaker to be inferred from the context. The use of SHALL in the meaning stipulated above is thus optional. However, if the writer chooses to indicate explicitly that the rules are warranted by a superior authority, SHALL becomes indispensable as in the three remaining verses.

Since authority may be exercised not only orally (cf. the use of inverted commas in (19) to underscore the directness of the experience) but also in writing, e.g. by signing legal or financial instruments, and superiority is manifest not only in laying down the rules or enacting laws but also in enforcing them by persons and institutions duly empowered to do so, the meaning identified above to be carried by SHALL can be restated in somewhat more general terms. Specifically it is claimed that SHALL is construed as a marker of authority vested in the author or authors of spoken and written texts.

Given this perspective on SHALL accounting for its usage in if clauses is not a problem any more, e.g. the following provision of the by-laws of the International Rugby Board, the organization governing the sport of rugby union:

(20) If the Chairman shall cease in office then the Vice - Chairman elected pursuant to Bye - Law 9.7(a) shall assume the position of Chairman pro - tem and the Council shall elect a new Chairman and Vice Chairman at its next meeting.

The underlined clause specifies the case when the vice-chairman steps into the shoes of the chairman and the use of SHALL merely explicates that the council that drafted and adopted this provision was duly authorized to do so.

The provision obviously might just as well have been formulated without resorting to SHALL and, for example, worded as follows:

(20') If the Chairman ceases in office then the Vice - Chairman elected pursuant to Bye - Law 9.7(a) shall assume the position of Chairman pro - tem and the Council shall elect a new Chairman and Vice Chairman at its next meeting.

The change would not have in any way affected the validity of the provision or the manner of its application. However, the fact that it was promulgated by an institution 
empowered to lay down rules and enforce them would then have to be inferred from a variety of contextual cues, e.g. the title of the document, its preamble, previous clauses, etc., while the use of SHALL in (20) makes that point explicit.

The same is the case with the use of SHALL in temporal clauses attested in legal English but left out of its descriptions surveyed in section 2 above, e.g. the following clause from the terms and conditions of sale posted online in 2010 by Company Select (UK) Limited, based in Telford, Shropshire :

(21) No order once placed may be cancelled by the Customer who will accept delivery of the goods or supply of the services from Company Select (UK) Limited when the Company shall so require.

Formulating the underlined clause without any recourse to SHALL again would not have caused any damage to the effectiveness of the provision, but only using that verb explicitly indicates that the company is authorized to stipulate such conditions and enforce them.

\section{Wider ramifications}

The account developed in the preceding sections sheds light a number of further issues discussed below. The most immediate one is identifying the reason why previous accounts of SHALL use in legal English have shied away from discussing its occurrence in temporal and conditional clauses.

The problem seems to have been rooted in assuming that SHALL has a principally deontic meaning (Witczak-Plisiecka 2009) and using it in a text is tantamount to imposing an obligation on the addresses (Trosborg 1995) or warranting that the text is a true representation of reality to the extent the situation is under the control of an intentional agent (Klinge 1995). However, as has been shown above, this approach is too narrow. Building on such an assumption makes it possible to account for SHALL uses in most main clauses, but rules out doing so in conditional and temporal clauses where no guarantees are offered or obligations imposed.

Secondly, the approach pursued above offers a straightforward explanation of the reason why the practitioners of simplifying legal English usually do not replace SHALL with other modal verbs but prefer to remove it and rephrase all affected clauses in the simple present (Williams 2007). If SHALL really profiled the imposition of an obligation, replacing it with MUST, HAVE TO, etc. would certainly make much more sense. However, as shown above, SHALL in fact designates that the author of a text is vested with sufficient authority to formulate it, which does not come anywhere close to the meaning of any other English modal verb but fortunately can be easily deduced from the context.

The efforts to eradicate SHALL from legal writing are thus ultimately based on the unspoken assumption that it is irreplaceable but removable, and, paradoxically, provide support for an account of its use.

Finally, the account of SHALL worked out above to explain its uses in conditional and temporal clauses can be extended to all types of clauses and legal documents. In 
instruments enacted by legislatures, assented to by monarchs, signed into law by presidents, approved by general meetings and issued by courts or administrative agencies the superiority of their real or imputed authors over the addressees is unquestionable. Citizens, subjects, company employees and parties to disputes are bound by the decisions written down in statutes, resolutions, charters, by - laws, judgments, orders, warrants, etc., which makes any such documents susceptible to the use of SHALL for reasons matching its description in section 5 .

In the case of deeds and contracts the situation is somewhat more egalitarian in that the parties to such instruments agree to create obligations for one another and promise to fulfill them (Black et al. 1983). Each party is thus both bound to perform the duties it owes to the counterparties and is empowered to exercise the rights the counterparties agreed to vest in it. Since all parties to a contract serve in both roles they are ultimately equal but that condition stems from the fact that they are each other's superiors. Consequently, the provisions of deeds and contracts also are susceptible to the use of SHALL for reasons that match its description in section 5.

Analyzing SHALL in terms of a marker of the authority vested in the author of a text corroborates thus the thetic account outlined in Conte and Di Lucia (2009) and makes it possible to account both for legal English usages which can be satisfactorily explicated in other frameworks and for those cases where other explanations fail, e.g. conditional and temporal clauses. As shown in the preceding sections, this account is also applicable to other fields of language use in which SHALL has outlived the pressure to phase it out, e.g. Bible translation, and is analogous to a well known and documented use of WILL. And last but not least, it explains why legal documents or religious texts may be fraught with SHALL, merely peppered with it here and there or devoid of it altogether without any impact on their validity as the meaning explicitly designated by that verb can be easily inferred from contextual clues.

\section{References}

Arnovick, Leslie K. 1990. The Development of Future Constructions in English. The Pragmatics of Modal and temporal Will and Shall in Middle English. Bern: Peter Lang.

Bergs, Alexander. 2008. Shall and shan't in contemporary English - a case of functional condensation. In: Trousdale, G. and Gisborne, N. (eds.) Constructional Approaches to English Grammar, pp. 113-144. Berlin: Mouton de Gruyter.

Black, H. 1983. Black's Law Dictionary. St. Paul: West Publishing Company.

Comrie, B. 1982. Future time reference in conditional protasis. Australian Journal of Linguistics 2: 143-152.

Conte, Amadeo G. and Paolo Di Lucia. 2009. Pragmatic ambiguity: the thetic function of modality. Lodz Papers in Pragmatics 5: 191-199. DOI: 10.2478/v10016-0090009-7

Declerck, Renaat. 1984. 'Pure future' will in if clauses. Lingua 63: 279-312. DOI: 10.1016/0024-3841(84)90036-6

Declerck, Renaat and S. Reed. 2001. Conditionals. A Comprehensive Empirical Analysis. Berlin: Mouton de Gruyter. 
Ellingworth, Paul. 2007. Translation techniques in modern Bible translation. In: Noss, $\mathrm{P}$ (ed.) A History of Bible Translation pp 307-334. Rome: American Bible Society.

Gotti, Maurizio, M. Dossena, R. Dury, R.Facchinetti and M. Lima. 2002. Variation in Central Modals. A Repertoire of Forms and Types of Usage in Middle English and Early Modern English. Bern: Peter Lang.

Gotti, Maurizio. 2003. Shall and will in contemporary English: a comparison with past uses. In: R.Facchinetti, M.Krug and F. Palmer (eds.) Modality in contemporary English pp. 267-300. Berlin: Mouton de Gruyter.

Kimble, Joseph. 2000. The Great Myth that Plain Language is not Precise. The Scribes Journal of Legal Writing 1998-2000: 109-119.

Klinge, Alex. 1995. On the linguistic interpretation of contractual modalities. Journal of Pragmatics 23: 649-675.

Leech, G., M.Hundt, Ch. Mair and N. Smith. 2009. Change in Contemporary English. Cambridge: Cambridge University Press.

Rissanen, M. 2000. Standardization and the language of early statutes. In: L. Wright. The Development of Standard English 1300 - 1800, pp. 117-130. Cambridge: Cambridge University Press

Trosborg, Anna. 1995. Statutes and contracts: an analysis of legal speech acts in the English language of the law. Journal of Pragmatics 23: 31-53. DOI:10.1016/03782166(94)00034-C

Visser, F. Th. 1963. An Historical Syntax of the English Language. Leiden: E.J. Brill.

Williams, Christopher. 2007. Tradition and Change in Legal English. Bern: Peter Lang.

Witczak-Plisiecka, Iwona. 2009. A note on the linguistic (in)determinancy in the legal context. Lodz Papers in Pragmatics 5: 201-226. DOI: 10.2478/v10016-009-0013-y 